\title{
Politik Identitas Kebalian dalam Musik Pop Bali
}

\author{
Ni Wayan Ardini \\ Program Studi Musik, Fakultas Seni Pertunjukan, Institut Seni Indonesia Denpasar \\ email: niwayanardini17@gmail.com.
}

\begin{abstract}
Identity politics concerns with the power of naming and describing many cultural aspects, including a cultural product called Balinese pop music in Balinese society. This study is managed as a literature review toward several relevant readings. Interview and analysis of discography are done to help the analysis. The study is carried out to know how the identity politics of Balinese works in the Balinese pop music and how it relates to discourses of power and knowledge. The result of the study shows that in Bali the identity politics is real in the phenomenon of the Balinese pop music representing identity marker in an era of globalization threats toward the Balinese society and culture in the last few decades. The Balinese language plays a very important role because such a factor showed whether a music is categorized into the Balinese pop music or not. However, nowadays, more and more Balinese pop songs which the tone scales are "less and less Balinese" and the way how the music is performed is "not Balinese" but also the lyrics are blended with foreign languages, especialy Indonesian.
\end{abstract}

Keywords: identity politics, Balinese pop music, discourse, power.

\begin{abstract}
Abstrak
Politik identitas berurusan dengan kekuasaan untuk menamai dan mendeskripsikan berbagai hal, termasuk benda budaya musik pop Bali dalam masyarakat Bali. Studi ini merupakan literature review terhadap sejumlah bacaan terkait. Wawancara dan penelahaan diskografi dilakukan untuk membantu analisis yang dilakukan. Tujuan studi ini adalah mengetahui bekerjanya politik identitas kebalian dalam musik pop Bali dan kaitannya dengan diskursus kekuasaan dan pengetahuan. Hasil studi menunjukkan bahwa di Bali politik identitas nyata dalam fenonema musik pop Bali yang direpresentasikan menjadi penanda identitas di tengah derasnya gempuran globalisasi terhadap masyarakat dan kebudayaan Bali dalam beberapa dasawarsa terakhir. Faktor bahasa Bali menjadi sangat penting karena bahasalah yang menunjukkan apakah musik berkategori musik pop Bali atau bukan. Belakangan yang terjadi adalah munculnya lagu-lagu yang tidak saja sistem tangga nadanya "tidak Bali" serta gaya penyajiannya sangat asing melainkan bahasanya sudah dicampur-campur dengan bahasa asing, terutama bahasa Indonesia.
\end{abstract}

Kata kunci: politik identitas, musik pop Bali, diskursus, kekuasaan.

\section{Pengantar}

Bali adalah bagian integral Negara Kesatuan Republik Indonesia. Karenanya, ideologi politik budaya lokal Bali dalam kemasan musik pop Bali dalam industrialisasinya yang telah berlangsung dalam tiga dasawarsa terakhir dengan sendirinya adalah salah satu sub-ideologi politik budaya Nusantara. Meskipun seakan-akan tidak hadir dalam pembicaraan ideologi politik budaya lokal dalam industrialisasi musik pop
Bali, negara (state) tetap ada dalam proses produksi, distribusi, dan konsumsinya. Sebagai contoh, pemerintah Indonesia berhak memberikan izin usaha dan mengenakan pajak dalam setiap produk musik pop Bali yang dijual atau dipertunjukkan di samping ikut mengatur keberlangsungan tata distribusi sampai mengontrol sejauh mana dampak yang ditimbulkan dalam konsumsi produkproduk terkait. 
Untuk menjaga keberlangsungan proses reproduksi produksi dan relasi produksi, negara dikembangkan sebagai struktur tertinggi yang memersatukan dan memaksa individu tetap rekat dan bergerak menjalankan proses-proses itu. Negara dengan aparatusnya menjaga dengan berbagai cara agar kondisi yang menunjang reproduksi dan relasi produksi berlangsung terus (Takwin, 2008). Althusser (2008: 19-20) membedakan dua jenis aparatus negara menjadi repressive state apparatus (RSA), seperti pemerintah, administrasi, angkatan bersenjata, polisi, pengadilan, penjara, dan sebagainya, yang bekerja dengan cara represif lewat penggunaan kekerasan dan ideological state apparatus (ISA) yang bekerja dengan cara persuasif dan ideologis, seperti agama, pendidikan, keluarga, hukum, politik, serikat buruh, komunikasi, dan budaya.

Berdasarkan penjelasan di atas, menarik melihat hubungan antara industrialisasi musik pop Bali dan konsepsi Althusser (2008) tersebut, terutama mengenai aparat negara ideologis (ISA), lebih-lebih dalam hal komunikasi dan budaya. Menurut Althusser (2008: 20), aparat negara ideologis komunikasi mencakup media massa, radio dan televisi, dan sebagainya, sedangkan aparatus negara ideologis budaya mencakup kesusasteraan, seni, olahraga, dan sebagainya. Produksi, distribusi, dan konsumsi musik pop Bali berkaitan dengan media massa, terutama radio dan televisi dan dengan seni di mana musik pop Bali adalah bagian dari seni itu sendiri.

Industrialisasi musik pop Bali karenanya bersesuaian dengan ideologi negara (di) Indonesia. Tanpa persetujuan negara, tidak mungkin pihak-pihak industri musik pop Bali dapat hidup dan beroperasi. Lebihlebih, dalam industrialisasi tersebut, bahkan sejak sebelum mengalami industrialisasi seperti saat ini, musik pop Bali berperan mendukung pembangunan kebudayaan Indonesia. Peran tersebut bahkan semakin dibutuhkan ketika Indonesia sudah berada dalam pusaran globalisasi di mana di dalamnya secara logika terdapat ancaman tertentu bagi kebertahanan budaya-budaya lokal, termasuk budaya Bali.

Semangat memertahankan budaya lokal sebagai reaksi terhadap gempuran globalisasi terlihat dalam ikhtiar para pelaku musik pop Bali, khususnya musisinya, untuk menjaga semaksimal mungkin aspek-aspek kebalian (balineseness), yakni eksistensi keetnikan Bali, dalam produk-produk musik yang dihasilkan. Dengan begitu, reaksi musikal seperti itu akan lebih membuat kebersandingan antara lokalisasi dan globalisasi.

Berdasarkan uraian di atas dan sesuai tema yang dipilih, dalam tulisan ini dibahas dua hal penting. Pertama adalah bagaimana politik identitas (identitiy politics) melalui produk budaya musik pop Bali mewujud dalam kehidupan masyarakat dengan segala kepentingannya. Kedua adalah bagaiman politik identitas musik pop Bali yang paling ditandai oleh keberadaan bahasa Bali, dari aspek kebahasaan tersebut, menjadi diskursus (dalam pengertian Foucault) yang berrelasi dengan kekuasaan dan pengetahuan, yang Foucault sendiri menyebutnya power/ knowledge.

Sesuai dengan permasalahan yang dibahas, teori utama yang digunakan untuk studi ini adalah Teori Relasi Kekuasaan/ Pengetahuan dari Michel Foucault (lahir 15 Oktober 1926 dan meninggal 25 Juni 1984). Bagus Takwin (2009: 109-112) memasukkannya ke dalam jenis teori ideologi. Menurut Takwin, (istilah) diskursus digunakan oleh Foucault sebagai pengganti ideologi. Penggantian ini dilakukan untuk menghindari pengertian ideologi dalam arti sebelumnya (2009: 112), yakni ideologi yang semata-mata merupakan persoalan yang muncul dari hubungan suprastruktur ("atas") dan substruktur ("bawah"). Kenyataannya, ideologi tidak saja berlangsung dalam hubungan antara struktur atas dan struktur bawah seperti hubungan antara 
negara dan masyarakat (disebut makro-politik). Ia juga menyebar dan merata, hingga mencakup kekuasaan-kekuasaan yang berskala kecil (disebut mikro-politik). Misalnya, dalam industrialisasi musik pop Bali, kekuasaan menyebar yang meliputi hubungan antara musisi dan produser/pemilik studio rekam yang sama-sama berada dalam satu ruang proses produksi. Bagi Foucault (Takwin, 2009: 109), ideologi merupakan hasil hubungan kekuasaan di mana saja.

Ideologi tentu tidak sama dengan pengetahuan dalam teori relasi kekuasaan/pengetahuan tetapi keduanya sejalan. Intinya adalah, dalam teori tersebut, kekuasaan ber-relasi dengan pengetahuan, di samping dengan ideologi. F. Budi Hardiman (2009) menunjukkan eratnya kaitan di antara ideologi, pengetahuan, kebenaran, dan makna di satu sisi, dan relasi ideologi, pengetahuan, kebenaran, dan makna tersebut dengan kepentingan dan kekuasaan di sisi lain. Hardiman berhasil menguraikan apa yang diniatkan Jurgen Habermas dari Mazhab Frankfurt dalam membongkar relasi antara pengetahuan dan kepentingan sebagai sebuah kritik ideologi.

Kekuasaan/ pengetahuan menyangkut keterkaitan antara kekuasaan dan pengetahuan sehingga produksi pengetahuan dipahami terkait dengan rezim kekuasaan. Analisis "genealogi" Foucault menguraikan relasi antara kekuasaan dan pengetahuan dan bagaimana relasi tersebut terjalin dalam formasi diskursif (discursive formation), yakni sebuah kerangka kerja konseptual yang memungkinkan diterimanya beberapa mode pemikiran dan ditolaknya beberapa mode pemikiran lainnya. Menurut Foucault (2002: 9), discourse tidak lain cara menghasilkan pengetahuan, beserta praktik sosial yang menyertainya, bentuk subjektivitas yang terbentuk darinya, relasi kekuasaan yang ada di balik pengetahuan dan praktik sosial tersebut, serta saling keterkaitan di antara semua aspek tersebut.
Bagi Foucault, diskursus adalah kerangka kerja yang ditentukan oleh yang berkuasa yang ditetapkan melalui hubungan-hubungan kekuasaan yang mendasarinya (dalam Fakih, 1997: 169). Setiap diskursus tentang kebudayaan tidak terlepas dari kepentingan dan kekuasaan.

Secara umum, tulisan ini menunjukkan karakteristik kemulti-/intersiplinan. Di satu sisi, ia merupakan sebuah kajian budaya (cultural studies) kritis dan di sisi lain, ia merupakan persoalan ilmu seni (study of arts), khususnya musik atau musikologi ( $m u$ sicology). Di samping itu, karena menyangkut aspek kebahasaan, ia bisa dilihat sebagai linguistik (ilmu bahasa), khususnya sosio-antropolinguistik. Bahkan lebih jauh, secara umum, ia juga merupakan sebuah studi politik (political studies) di mana studi ini sangat beririsan dengan kajian budaya yang memang bersifat politik (political).

Studi ini bersifat kualitatif dan dengan demikian analisisnya merupakan analisis data kualitatif (qualitative data analysis). Sosok studi ini merupakan suatu literature review atau tinjauan pustaka. Sejumlah kepustakaan ditelaah, baik yang menyangkut persoalan-persoalan yang dibahas (aspek ontologi) maupun teori yang digunakan (aspek epistemologis). Perlu dikemukakan bahwa, selain wawancara, studi ini juga menggunakan discography, yakni menelaah karya seni yang relevan, dalam hal ini produk-produk musikal, yang dihasilkan seniman yang dibahas.

\section{Pembahasan}

\section{Politik Identitas Kebalian melalui} Musik Pop Bali

Meskipun sekarang adalah era globalisasi di seluruh belahan dunia di mana arah menuju global(isasi) seringkali mengalahkan arah yang sebaliknya (lokalisasi), banyak hal yang bisa dijadikan sebagai penanda identitas (identity marker) orang Bali dan "bukan orang Bali". Secara umum, bahasa, pakaian, penampilan, tingkah laku, tata upacara 
keagamaan, kesenian, dan termasuk musik popnya, yakni musik pop Bali, tetap mampu menandai bahwa seseorang bisa disebut orang Bali atau tidak. Hal ini dapat dibandingkan dengan kenyataan bagaimana orang Jawa ditandai musik pop Jawa, orang Sunda ditandai musik pop Sunda, atau orang Batak ditandai musik pop Batak.

Politik identitas terkait erat dengan politik posmodernisme dengan adanya asumsi kegagalan mimpi-mimpi modernitas memperbaiki situasi kehidupan. Untuk konteks Indonesia, politik identitas senada dengan gerakan desentralisasi (otonomi daerah) yang terjadi sejak era Reformasi (1998) dengan gagalnya gerakan modern pembangunanisme Orde Baru menata kehidupan masyarakatnya. Bentuknya adalah terjadinya politik identitas dengan muncul dan menguatnya semangat daerahisme. Salah satunya adalah berkibarnya politik identitas bidang musik pop daerah, termasuk musik pop Bali.

Politik identitas kebalian (balineseness) atau politik keetnikan (etnisitas) Bali tidak lain adalah sebuah politik budaya (cultural politics). Politik (ke)budaya(an) sebagai sebuah ideologi sangat terkait dengan kekuasaan yang mengonstruksi pengetahuan-pengetahuan, makna-makna, dan kebenaran-kebenaran dalam politik budaya tersebut. Politik budaya sendiri, menurut Barker (2014: 59),

Politik budaya adalah soal kekuasaan untuk menamai, dan mengesahkan, objekobjek dan peristiwa-peristiwa yang mencakup versi resmi (official) dan versi tidak resmi (common sense) dari dunia sosial dan budaya. Salah satu argumen pokok dalam kajian budaya adalah budaya dipahami sebagai "wilayah" (domain) di mana pelbagai makna dan versi tafsir tentang dunia dan kenyataan saling berkompetisi, berjuang untuk diperhatikan, dan diakui. Secara khusus, makna dan kebenaran dibentuk dalam pola-pola kekuasaan dan masuk dalam proses kontestasi (perlombaan). Dengan demikian, politik budaya bisa dimengerti dalam bingkai kemampuan untuk merepresentasikan dunia dan membuat sejumlah deskripsi (tentang dunia tersebut) jadi lebih "melekat" (stick).

Terkait dengan hal itu, Barker (2014: 134) juga menyatakan,

Politik identitas (identity politics) adalah turunan dari politik budaya, dan dengan demikian juga berurusan dengan "kekuasaan untuk menamai" dan untuk membuat sejumlah deskripsi tertentu "lebih akrab" (stick). Secara khusus, representasi identitas adalah persoalan politis karena hal ini terkait dengan persoalan kekuasaan sebagai bentuk regulasi sosial yang memproduksi diri dan yang memampukan sejumlah identitas eksis, sementara yang lain tidak (karena disangkal dan ditekan).

Dalam industrialisasi musik pop Bali, selain Nanoe Biroe yang kuat menancapkan ideologi kebaliannya meskipun penampilan fisiknya "tidak Bali", [XXX] adalah salah satu kelompok musisi yang paling tegas menyatakan kecintaannya kepada identitas kebalian melalui ekspresinya dalam kesenian musik Bali (Mereka sering menggunakan istilah musik Bali untuk musik pop Bali).

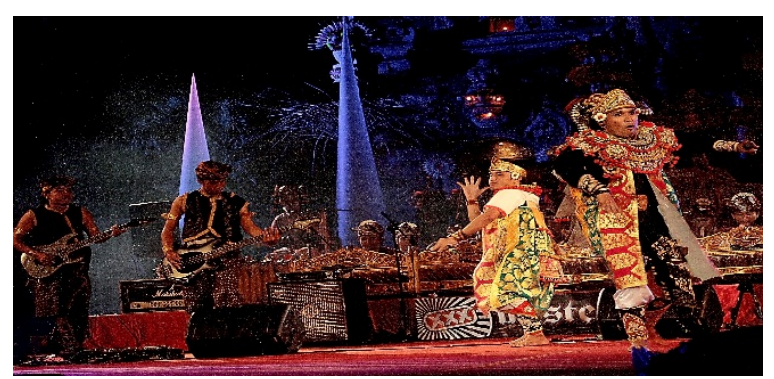

Ilustrasi 1.

Sebuah pertunjukan $[X X X]$ dengan identitas tradisional kebaliannya pada PKB 2013 di Panggung Ardha Candra, Denpasar (Foto: Repro/[XXX], 2017)

Tampaknya mereka tidak main-main dalam membanggakan dirinya sebagai orang Bali yang membawakan musik berbahasa Bali dengan mengangkat kehidupan Bali yang dicampur-campur unsur-unsur musikalitas global, seperti rock, rap, reggae, 
dan sebagainya, dengan hasil yang di atas rata-rata. Di balik nama kelompok dan penampilan beberapa anggotanya yang "tidak Bali", konsep-konsep musikalitasnya sangat bersemangat Bali. Masyarakat Bali yang menggemarinya pun menyambut produkproduk musiknya secara positif.

Salah satu lagu $[X X X]$ yang paling tepat mewakili produk-produk musik pop Bali sebagai penanda identitas orang Bali adalah ciptaan Rah Tut yang berjudul "Nak Bali" di mana di dalamnya dituturkan secara polos persoalan "saya anak Bali, berbahasa Bali, menyanyi (lagu) Bali". Pesan politik lagu andalan dalam album [XXX] tersebut tergolong sederhana tetapi secara musikalitas menarik dinikmati karena musik pop Bali dicampurcampur genre rock dan rap sebagaimana yang sering dilakukan kelompok ini dalam lagu-lagunya dan terutama secara ideologis sangat mewakili perasaan dan cita-cita para musisi Bali dan bahkan masyarakat Bali pencinta musik pop Bali. Pesan yang dimaksud adalah "sebagai orang Bali sebaiknya menyintai musik Bali". Secara diam-diam, hal ini merupakan sebentuk politik identitas kebalian yang dimaksudkan kelompok yang salah seorang anggotanya, yakni Rah $\mathrm{Tu}$, justru berpenampilan bukan seperti orang Bali umumnya dan beristrikan bule asal Australia.

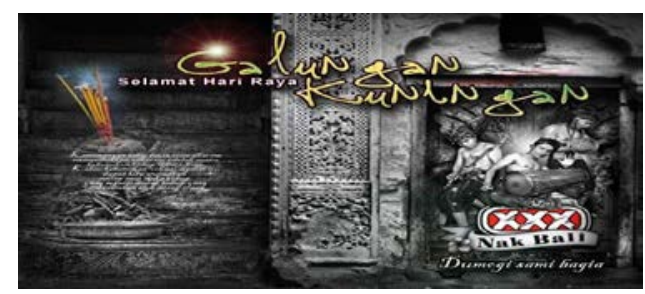

Iluistrasi 2.

Cover album Nak Bali (2011) yang menunjukkan fitur-fitur identitas kebalian (Foto: Repro/ [XXX], 2017)

Bagi [XXX] dan penikmat musiknya, lagu ini boleh jadi dianggap biasa-biasa saja dan tidak politik(al) tetapi tidak demikian halnya bila dilihat dalam konteks ilmu

pengetahuan, khususnya secara kajian budaya kritis (critical cultural studies). Lagu ini dapat merepresentasikan jiwa industrialisasi, khususnya para musisi, pop Bali di tengah pembangunan kesenian yang dimotori pemerintah. Masyarakat Bali pencinta musik pop Bali pun memiliki cita-cita yang sama. Melalui lagu ini, [XXX] semacam berkomitmen mengembangkan sikap toleransi dan demokratisnya yang penuh kebebasan kepada mereka yang suka dan yang tidak suka musik pop Bali. Baginya, menyanyikan musik Bali adalah cara ngajegang (melestarikan) serta menghormati Bali.

\begin{tabular}{|c|c|}
\hline I & NAK BALI \\
\hline $\begin{array}{l}\text { Dadi ngaku uling Bali yen } \\
\text { ba nyak ngaku uling Bali }\end{array}$ & $\begin{array}{l}\text { Boleh mengaku dari } \\
\text { Bali kalau sudah } \\
\text { mengaku dari Bali }\end{array}$ \\
\hline $\begin{array}{l}\text { Dini laku kumpul-kumpul } \\
\text { ngalih timpal }\end{array}$ & $\begin{array}{l}\text { Di sini kumpul-kumpul } \\
\text { cari } \\
\text { teman }\end{array}$ \\
\hline $\begin{array}{l}\text { Bareng-bareng jak make- } \\
\text { jang } \\
\text { Demen-demen saling } \\
\text { kenyemin } \\
\text { Sareng sami magending } \\
\text { magending Bali... }\end{array}$ & $\begin{array}{l}\text { Bersama-sama } \\
\text { semuanya } \\
\text { Senang-senang saling } \\
\text { beri senyum } \\
\text { Bersama-sama } \\
\text { menyanyi menyanyi } \\
\text { Bali... }\end{array}$ \\
\hline $\begin{array}{l}\text { Yadiastun tiang magend- } \\
\text { ing Bali } \\
\text { Sing buwungan ada ne de- } \\
\text { men ada ne sing demen }\end{array}$ & $\begin{array}{l}\text { Meskipun saya } \\
\text { menyanyi Bali } \\
\text { Tidak terelakkan ada } \\
\text { yang suka ada yang } \\
\text { tidak suka }\end{array}$ \\
\hline $\begin{array}{l}\text { Nah depang ja keto de, nah } \\
\text { depang sing kenken de, }\end{array}$ & $\begin{array}{l}\text { Nah biarkan saja begitu } \\
d e, n a h \text { biarkan saja } \\
\text { tidak apa-apa } d e,\end{array}$ \\
\hline $\begin{array}{l}\text { Nyen nawang ya mula } \\
\text { sing ngerti } \\
\text { Sing ada luwungan ma- } \\
\text { gending Bali } \\
\text { Pang bisa pang nawang } \\
\text { ngajiang Bali } \\
\text { Nyen ne ngorahang de, } \\
\text { nyen ne ngelah de } \\
\text { Yen sing iraga padidi ne } \\
\text { ngelahang }\end{array}$ & $\begin{array}{l}\text { Siapa tahu ia hanya } \\
\text { tidak mengerti } \\
\text { Tak ada lebih bagus } \\
\text { dari menyanyi Bali } \\
\text { Agar bisa agar tahu } \\
\text { menghormati Bali } \\
\text { Siapa yang bilang de, } \\
\text { siapa yang punya de } \\
\text { Kalau tidak ki ta sendiri } \\
\text { yang punya }\end{array}$ \\
\hline $\begin{array}{l}\text { Anak Bali, tiang anak Bali, } \\
\text { mabasa Bali, magending } \\
\text { Bali }\end{array}$ & $\begin{array}{l}\text { Anak Bali, saya anak } \\
\text { Bali, berbahasa Bali, } \\
\text { bernyanyi Bali }\end{array}$ \\
\hline
\end{tabular}




\begin{tabular}{|c|c|}
\hline $\begin{array}{l}\text { Dadi nak Bali yen melali } \\
\text { pasti mawali mulih ke Bali }\end{array}$ & $\begin{array}{l}\text { Jadi anak Bali kalau } \\
\text { melancong pasti kem- } \\
\text { bali pulang ke Bali }\end{array}$ \\
\hline $\begin{array}{l}\text { Yadiastun joh joh joh } \\
\text { tiang melali } \\
\text { joh joh joh tiang megae }\end{array}$ & $\begin{array}{l}\text { Meskipun jauh jauh } \\
\text { jauh saya melancong } \\
\text { jauh jauh jauh saya } \\
\text { bekerja }\end{array}$ \\
\hline $\begin{array}{l}\text { Tiang lakar mulih jeg pasti } \\
\text { mulih mulih ke Bali }\end{array}$ & $\begin{array}{l}\text { Saya akan pulang toh } \\
\text { pasti pulang pulang ke } \\
\text { Bali }\end{array}$ \\
\hline Magambel... gitar... & $\begin{array}{l}\text { Mainkan gamelan... gi- } \\
\text { tar... }\end{array}$ \\
\hline $\begin{array}{l}\text { Yen mula seken ngajegang } \\
\text { Bali }\end{array}$ & $\begin{array}{l}\text { Kalau memang benar } \\
\text { melestarikan Bali }\end{array}$ \\
\hline $\begin{array}{l}\text { Lan bareng-bareng ngas- } \\
\text { titi bakti }\end{array}$ & $\begin{array}{l}\text { Ayo bersama-sama } \\
\text { sujud hormat }\end{array}$ \\
\hline $\begin{array}{l}\text { Yen mula demen jak gumi } \\
\text { Bali }\end{array}$ & $\begin{array}{l}\text { Kalau memang suka } \\
\text { pada tanah Bali }\end{array}$ \\
\hline $\begin{array}{l}\text { Magending gending lau- } \\
\text { tang jani }\end{array}$ & $\begin{array}{l}\text { Bernyanyi-nyanyi } \\
\text { silakan saja }\end{array}$ \\
\hline Еее...ооо...еее...ооо... & Еее...ооо...еее...ооо... \\
\hline
\end{tabular}

Ilustrasi 3.

Teks lagu "Nak Bali" diambil dari album Nak Bali (2011).

Pandangan $[X X X]$ tentang "identitas" dalam kaitan dengan musik pop Bali pantas dicermati. Dalam release-nya yang dikeluarkan pada Rabu, 20 Juli 2011, [XXX] memahami identitas dengan menulis pernyataan sebagai berikut,

"Identitas itu tidak pernah tetap, tidak utuh, tidak satu tetapi terus digodok dalam proses. Artinya, bahwa identitas itu akan terus berubah, terus dikonstruksi dalam proses. Mungkin kita tidak perlu pesimis mendengar jawaban bahwa lagu Bali tidak memiliki identitas karena identitasnya bergulir terus dalam proses. Berbagai jenis aliran musik sudah dapat kita dengarkan saat ini. Bukan hambatan untuk mencoba sesuatu yang berbeda dalam berkarya khususnya musik. "Bebas", kata yang paling cocok untuk mencoba hal tersebut. Kebebasan untuk menghasilkan yang berbeda. Tanpa harus dikait-kaitkan dengan merusak atau melupakan budaya kita, selama tetap dalam jalur berkesenian. Berek- sperimen mencoba terobosan baru. Itulah seni. Baik itu dalam seni rupa, seni tari, seni musik dsb. Penuh dengan proses-proses pencarian. Demikian pula dalam pencarian identitas lagu Bali itu sendiri. No name, no identity but freedom. Biarkan berjalan mengikuti waktu dan jaman."

Pernyataan tersebut dapat dikata-kan kredo dan ideologi [XXX] dalam berkarya. Identitas dianggap sebagai sesuatu yang tidak pernah tuntas, selalu bergerak, dan selalu mencari yang baru. Itulah sebabnya, bagi mereka, yang penting bukan identitas melainkan kebebasan untuk berkarya. Semua ini dibuktikannya lewat karya-karya (album) yang tidak mudah diberikan identitas karena bergerak lincah dan estetik di antara musik pop, rock, rap, reggae, irama Melayu, dan sebagainya sebagai satu kesatuan musik pop Bali yang bebas, yang disebutnya "lagu Bali". Di balik semua itu, tampak jelas bahwa $[X X X]$ yang berasal dari keluarga tri wangsa (bangsawan) di Klungkung sangat menyintai seni-budaya Bali.

Musik pop Bali secara umum saat ini sudah diterima sebagai bagian dari seni-budaya atau kebudayaan Bali. Bagaimana musik pop Bali akhirnya bisa dianggap seperti itu tidak langsung serta-merta terjadi. Ada proses yang tidak mudah yang membutuhkan waktu tertentu di dalamnya. Menurut seniman serba bisa sekaligus wartawan senior Bali Gus Martin (Ida Bagus Martinaya) dalam sebuah makalahnya "Musik Pop Bali itu, Keberagaman itu" dalam Sarasehan Lagu Pop Bali di Denpasar tanggal 30 Juli 1999,

“Dalam perjalanannya, keberadaan musik pop Bali pada awalnya dianggap sebagian kalangan sebagai 'anak tiri' dalam gugus cakrawala kesenian Bali. Musik pop Bali tidak begitu saja diterima sebagai 'keluarga' kesenian Bali. Contoh kecil di Pesta Kesenian Bali (PKB) pada awal-awalnya, misalnya, musik pop Bali sama sekali tak 
masuk agenda pentas. Musik pop Bali masih dianggap sebagai 'bukan pentas kesenian Bali' ".

Seanjutnya ia mengatakan bahwa:

"Bentuk musik pop Bali juga pernah menjadi perdebatan dilematif antar pengamat, musisi, seniman, sampai birokrat. Sebagian dari mereka -pengamat, musisi, seniman- berpendapat, musik pop Bali yang lahir dari industri rekaman seperti yang dilakukan AA Made Cakra hingga Young (sic) Sagita sebagai kesenian pasaran, tak bermutu, dan bukan 'kesenian Bali'. Terlebih, pendapat ini muncul, ketika maraknya lahir sejumlah lagu yang syairnya sarat mengandung hal-hal yang berbau porno, vulgar, dan sering merusak bahasa Bali itu sendiri."

Musik pop Bali saat diperkenalkan Cakra melalui Putra Dewatanya pada dasawarsa 1970-an sering dianggap bukan senibudaya Bali. Alat-alat musik yang digunakan Cakra dan kawan-kawannya tergolong instrumen modern (gitar, drum, biola, dan sebagainya) dan tidak memakai instrumen tradisional Bali yang sesungguhnya cukup kaya untuk menopang musik pop Bali yang benar-benar berazas glokal (global-lokal). Justru belakangan, ketika terjadi industrialisasi yang signifikan, alat-alat musik tradisional Bali digunakan sebagai sekadar sisipan untuk memaniskan musik (lagu) dan terutama untuk ikut menandai bahwa itu adalah "musik Bali". Sering di sela-sela permainan musik, dimasukkan sistem suara alat musik tradisional yang sudah diprogram dalam keyboard. Itulah cara mereka mengungkapkan kebalian musik pop Balinya.

Terkait dengan program infotainment (informasi dan entertainment) yang berhubungan dengan musik pop Bali "Samatra Artis Bali" di Bali TV (setiap Minggu pukul 20.0021.00 Wita), dalam iklan-iklan program ini, terdapat kalimat "ngiring ngelestariang seni- budaya Bali" yang mengindikasikan musik pop Bali digolongkan bagian tersendiri dari seni-budaya Bali. Ini berarti bahwa ada pernyataan ideologis bahwa musik pop Bali, sebagai salah satu bentuk kesenian atau seni musik, termasuk kebudayaan Bali.

Dalam membahas politik identitas kebalian, gerakan balinisasi ajeg Bali harus disebutkan karena ideologi prakarsa Kelompok Media Bali Post (KMB) pimpinan Satria Naradha ini senada dengan visi musik pop Bali. Menurut Nordholt (2007: 55), selama dasawarsa 1990-an, dan khususnya di bawah Satria Naradha, Bali Post menjadi bisnis media tingkat provinsi yang sangat kuat, yang sekarang mencakup stasiun televisi lokal, empat stasiun radio, surat kabar Bali Post yang sangat dihormati, harian Denpost yang terutama mengkover kriminalitas, dan sejumlah surat kabar dan majalah.

Ajeg Bali diluncurkan pada pembukaan Bali TV pada bulan Mei 2002 ketika Gubernur Bali I Dewa Made Bratha menyarankan audiensnya untuk meng-ajegkan adat dan budaya (Nordholt, 2007: 55-56). Bali TV sebagai anak perusahaan KMB bahkan memiliki program talk show bernama "Ajeg Bali" setiap hari Jumat pukul 17.0518.00 yang menjadi junjungan dan arena diskusi yang tepat bagi mereka yang ingin menjaga adat dan budaya Bali. Sudah pasti adat dan budaya Bali yang dimaksud mengacu pada agama Hindu yang menjadi agama mayoritas penduduk Bali. Nordholt (2007: 56) juga mengatakan, orang Bali umumnya menyukai konsep berikut.

\footnotetext{
- "Ajeg bermakna bahwa kita harus kembali ke keaslian. Kembali ke Bali yang murni dan damai, ketika segala sesuatu berjalan teratur dan benar."

- "Ajeg bermakna bahwa Bali aman dan dapat melawan terorisme."

- "Ajeg Bali menawarkan kepada kita sebuah jawaban terhadap modernisme tanpa substansi."
} 
Dari pandangan ("pengetahuan") Nordholt (2007) tentang ajeg Bali di atas menunjukkan betapa kekuasaan bersifat menyebar sebagai mikro-politik sebagaimana yang secara umum menjadi pandangan Foucault. Kekuasaan saat ini tidak saja dimiliki pemerintah (negara) dan pejabatnya tetapi juga dimiliki sumber daya media, dalam hal ini Kelompok Media Bali Post. Dalam diskursusnya, ajeg Bali sendiri seolah-olah merepresentasikan kekuasaan rakyat setelah begitu lama kekuasaan rakyat (demokrasi) ditindas kekuasaan pemerintah Orde Baru (19661998). Masing-masing membentuk "pengetahuan"-nya sendiri yang disampaikan kepada pihak lain sebagai kebenaran.

Pengetahuan-pengetahuan atau kebenaran-kebenaran tentang ajeg Bali yang disampaikan oleh seluruh kekuasaan yang ada bersifat diskursif yang menurut Foucault (dalam Barker, 2005: 106) berada dalam kerangka "formasi diskursif" atau pembentukan diskursus. Menurut Satria Naradha (2004) sendiri sebagai penggagas ajeg Bali dan sekaligus pemilik Bali Post dan Bali TV, ajeg Bali bukanlah sebuah konsep yang stagnan melainkan sebuah upaya pembaruan terus-menerus yang dilakukan secara sadar oleh manusia Bali. Tujuannya adalah menjaga identitas budaya Bali. Upaya ini akan bermuara pada cita-cita peningkatan kekuatan manusia-manusia Bali agar tidak jatuh di bawah penaklukan hegemoni budaya global. Dengan itu, Bali tetap dan akan selamanya Bali dengan segenap peradaban Hindu dan budaya Balinya di mana orangorangnya setia pada seni-budaya dan agama yang ada.

Ajeg Bali sebagai konsep politik atau ideologi tidak bisa dipisahkan dari munculnya politik desentralisasi dalam bentuk otonomi daerah di tingkat II (kabupaten/kota) di seluruh Indonesia pascagerakan reformasi nasional pada tahun 1998 sebagai dekonstruksi terhadap sentralisme kekuasaan Orde Baru pimpinan Presiden Soeharto. Ajeg Bali tampak seideologis otonomi daerah tetapi ajeg Bali dimaksudkan untuk konteks Bali, atau tepatnya Provinsi Bali sedangkan otonomi daerah yang dimaksud berlangsung di tingkat kabupaten/kota dan tidak di tingkat provinsi. Intinya, ajeg Bali adalah bagaimana upaya-upaya pemberdayaan krama (masyarakat) Bali harus direalisasikan. Tujuannya agar orang Bali menjadi "tuan rumah di negerinya sendiri." Ajeg Bali diasumsikan berbasis dan memberdayakan manusia dan budaya Bali.

Diskursus ajeg Bali diasumsikan untuk menghadapi segala macam ancaman dan tantangan terhadap Bali, baik secara politik, keamanan, ekonomi, sosial, budaya, agama, dan lingkungan. Seperti diketahui, pada malam tanggal 12 Oktober 2002, secara mengejutkan di Legian, Kuta, sebuah bom berskala besar meledak dan meluluhlantahkan sebuah fasilitas pariwisata yang sarat pengunjung. Bom tersebut menewaskan ratusan orang tidak berdosa, baik pengunjung (wisatawan) dan karyawan, yang berasal dari mancanegara maupun Indonesia dan Bali sendiri. Bom diledakkan sejumlah teroris asal Indonesia yang sebagiannya dihukum mati pada tahun 2008 di mana semuanya berasal dari elemen-elemen garis keras Islam dalam perjuangannya yang digambarkan melawan kekejaman Amerika Serikat terhadap Islam.

Gerakan pengembangan musik pop Bali relevan dengan ideologi ajeg Bali, yakni sebagai bentuk perlawanan kesenian (musik) Bali menghadapi musik-musik yang berasal dari luar yang sejak lama menjajah Bali. Selain Bali TV yang memiliki program "Klip Bali", "Tembang Bali", dan "Samatra Artis Bali", DenPost (Kelompok Media Bali Post) sempat mengadakan acara tahunan bertajuk Gita Denpost Award (GDA) sampai dengan 2008 sebagai penghargaan kepada insan-insan musik Bali (terutama musik pop Bali) yang dianggap berprestasi dengan kriteriakriteria yang ditetapkannya. Tidak diperoleh data yang akurat mengapa ajang yang begitu prestisius dan positif bagi perkembangan 
musik pop Bali tiba-tiba berhenti di tengah jalan.

Meskipun belakangan timbul sinyalamen hanya merupakan gerakan kapitalisme media dan dinilai gagal dalam sejumlah hal, ideologi ajeg Bali, dalam konteks industrialisasi musik pop Bali, tetap dibutuhkan, paling tidak semangat dan tujuannya. Sejumlah musisi pop Bali lewat karya-karyanya yang bernafaskan dan bahkan bertemakan ajeg Bali menyuarakan hal ini, seperti $[X X X]$ dan Nanoe Biroe yang cukup populer. Tentu saja lagu-lagu tersebut adalah representasi musik pop Bali yang bersifat ideologis. Betapa pun ajeg Bali begitu hegemonik dan menjadi semacam kesadaran palsu dalam masyarakat, upaya-upaya tulus memberdayakan potensi masyarakat dan kebudayaan Bali harus benar-benar dimanifestasikan untuk tujuan masyarakat dan kebudayaan Bali itu sendiri.

\section{Bahasa Bali Sebagai Penanda Identi- tas Terpenting Musik Pop Bali}

Berbicara ideal-normatif, terdapat sejumlah elemen terpenting kebudayaan lokal (kebudayaan Bali) dalam musik pop Bali. Pertama adalah bahasa Bali, kedua adalah alat musik tradisional Bali dengan sistem notasi pentatonik yang digunakan untuk mencampur ramuan musikalitas, dan ketiga adalah penyajian musik pop Bali dan penampilan musisinya. Di bagian ini hanya akan dibahas permasalahan pertama (bahasa Bali) karena elemen inilah yang relatif paling menandai mengapa musik pop Bali disebut "musik pop Bali". Kenyataannya, semakin lama, semakin muncul kecenderungan bahwa aspek-aspek alat musik, sistem notasi, gaya penyajian musik dan penampilan musisi, dan konten (pesan) lagu tidak lagi menunjukkan kebalian. Bahasa Bali dalam syair/lirik musik pop Bali pun mengalami masalahnya sendiri.

Idealnya musik pop daerah, termasuk musik pop Bali, menunjukkan arah glo- kal(isasi) dan bukan globalisasi saja atau lokalisasi saja karena musik pop Bali mengacu kepada paduan antara global dan lokal secara proporsional, adil, dan harmonis dan tidak saling mengalahkan satu sama lain. Kenyataan yang terjadi dalam musik pop Bali adalah sistem notasi lagu yang berkembang dari pentatonik ke diatonik, alat musiknya semakin teknologis sehingga alat-alat musik tradisional (dan musisinya) terpinggirkan, gaya penampilan musisi tidak ubahnya musisi Barat, dan pesan lagu tidak lagi Bali.

Menjelang dasawarsa 2000-an, di Bali ada kontroversi terkait dengan kecenderungan seperti di atas. Sejumlah pakar mengritisi besarnya globalisasi melanda musik pop Bali sedangkan ada juga yang realistis dengan menyatakan bahwa musik pop Bali boleh berbentuk apa saja asalkan bahasanya tetap Bali. Ada musik industri (komersial) dan ada musik festival. Kalau musik yang disebut pertama mengandalkan kebebasan asalkan easy listening dan diterima pasar luas (menguntungkan secara ekonomis) sedangkan yang kedua memertahankan polapola seni-budaya Bali, seperti sistem notasi dan tema yang dipilih. Seperti mendamaikan polarisasi tersebut, dalam sebuah makalahnya pada Sarasehan Lagu Pop Bali di Denpasar tanggal 30 Juli 1999, Gus Martin menyatakan bahwa lagu (maksudnya musik) pop Bali cukup mengambil kriteria sederhana saja, yaitu lagu tersebut harus memakai lirik/syair bahasa Bali.

Secara umum bahasa sendiri tidak dapat dipisahkan dari ideologi. Di balik bahasa ada ideologi. Ideologi terekspresi lewat bahasa. Lewat bahasa, ideologi mendapatkan wadah pengungkapannya. Takwin (2003: 101) berpendapat, filsuf asal Uni Soviet VN Volosinov mampu melihat ideologi sebagai hasil dari internalisasi kata-kata yang termuat dalam bahasa. Menurut Volosinov, kesadaran hanya dapat muncul dalam wadah material dari penanda-penanda (signifiers). Sedangkan penanda-penanda sendiri 
bersifat material, bukan hanya cerminan dari realitas melainkan menjadi satu dengan realitas yang ditandainya. Bagi Volosinov, tanpa tanda (signs), tidak ada ideologi.

Volosinov ingin menunjukkan bahwa ideologi tidak hanya dilatari dasar ekonomi tetapi juga melibatkan aspek linguistik dan sifat materialistik dari kata sebagai tanda. Dengan demikian, ideologi bukan sekadar tanggapan refleks terhadap masalah ekonomi tetapi melibatkan juga konteks penggunaan bahasa dalam keseharian manusia (Takwin, 2003: 102). Berdasarkan pandangan Volosinov tersebut, dapat dikatakan bahwa bahasa Bali adalah ideologi tersendiri dalam industrialisasi musik pop Bali. Bahasa Bali adalah penanda identitasnya meskipun bukan satu-satunya.

Ketidakmampuan bahasa Bali, yang diakibatkan ketidakmampuan masyarakat pengguna bahasa, termasuk musisi pop Bali itu sendiri, menjadi salah satu faktor utama mengapa ada musisi yang memilih mencampur-campur bahasa Bali dengan bahasa Indonesia atau bahasa asing. Sebagai contoh, kata yang paling umum dalam produk musik bertema cinta, yakni panggilan sayang (bahasa Indonesia), yang merupakan padanan baby dalam bahasa Inggris mau tidak mau akhirnya digunakan secara paksa dalam syair musik pop Bali karena belum ada kata yang benar-benar sepadan dengannya dalam bahasa Bali. Kalaupun kata itu ada dalam bahasa Bali, kata yang muncul dianggap kampungan, sehingga kata sayang tetap dimasukkan dan tampaknya berterima umum karena sense-nya lebih tepat dan gaul (sesuai konteks).

KIS Band dalam album-albumnya selalu melakukan penyimpangan kebahasaan yang dimaksud. Dilihat dari unsur judul lagu, KIS Band paling sering mengeluarkan musik pop Bali dengan judul yang tidak menggunakan bahasa Bali standar meskipun bahasa judul tidak secara langsung mencerminkan bahasa syair lagu. Setiap albumnya secara umum digolongkan musik pop Bali meskipun ada beberapa lagu berbahasa Indonesia dan bahkan berbahasa Inggris di dalamnya. Ada lagu dengan judul bahasa Indonesia tetapi syairnya kebanyakan atau sepenuhnya berbahasa Bali atau demikian sebaliknya. Namun demikian, apa yang dilakukan KIS Band melalui keempat albumnya menarik dianalisis untuk menjelaskan keadaan industrialisasi musik pop Bali dari hubungan antara produk-produk yang ada dengan aspek kebahasaannya.

Tabel 1. Perbandingan Aspek Kebahasaan Musik Pop Bali dalam Kasus Judul Lagu Album KIS Band

\begin{tabular}{|c|c|c|c|c|}
\hline $\begin{array}{l}\text { Album } \\
\text { Jugul } \\
\end{array}$ & $\begin{array}{c}\text { \#1 (Number One) } \\
\text { (2010, album } \\
\text { pertama) }\end{array}$ & $\begin{array}{c}\text { Jahat } \\
\text { (2012, album } \\
\text { kedua) }\end{array}$ & $\begin{array}{c}\text { Sakit Jiwa } \\
\text { (2013, album } \\
\text { ketiga) }\end{array}$ & $\begin{array}{c}\text { Story of Me } \\
(2014)\end{array}$ \\
\hline $\begin{array}{l}\text { Lagu dengan } \\
\text { judul bahasa } \\
\text { Bali }\end{array}$ & $\begin{array}{l}\text { "Timpal } \\
\text { Curhat", "Ije } \\
\text { Jani Adi", } \\
\text { "Ayang (Sing } \\
\text { Tepat)" }\end{array}$ & $\begin{array}{l}\text { "Kanti } \\
\text { Semengan", } \\
\text { "Gaenang Melah } \\
\text { Iraga } \\
\text { Megatang", } \\
\text { "Suba Peteng" }\end{array}$ & "Endrin"* & $\begin{array}{l}\text { "Dibi Bli } \\
\text { Punyah" }\end{array}$ \\
\hline $\begin{array}{l}\text { Lagu dengan } \\
\text { judul bahasa } \\
\text { Indonesia }\end{array}$ & $\begin{array}{l}\text { "Semangat } \\
\text { Membara } \\
\text { Berjiwa } \\
\text { Pemenang", } \\
\text { "Bapak Mabok" }\end{array}$ & $\begin{array}{l}\text { "Main Api", } \\
\text { "Si Bodoh", } \\
\text { "Halilintar", } \\
\text { "Jahat", } \\
\text { "Insting", } \\
\text { "Penyakit } \\
\text { Cinta", }\end{array}$ & $\begin{array}{l}\text { "Petir } \\
\text { Menyambar", } \\
\text { "Sakit Jiwa", } \\
\text { "Roda Gila", } \\
\text { "Endrin"* } \\
\text { "Pasal 335", } \\
\text { "Ingat Kamu", }\end{array}$ & $\begin{array}{l}\text { "Sayang Pasti } \\
\text { Kita Bisa", } \\
\text { "Berbohong- } \\
\text { lah", "Esa } \\
\text { Hilang Dua } \\
\text { Terbilang", } \\
\text { "Tahukah }\end{array}$ \\
\hline
\end{tabular}




\begin{tabular}{|c|c|c|c|c|}
\hline & & $\begin{array}{l}\text { "Aku Mau } \\
\text { Kamu", } \\
\text { "Sabar" }\end{array}$ & & $\begin{array}{l}\text { Kamu", } \\
\text { "Berjuang } \\
\text { untuk } \\
\text { Cinta", }\end{array}$ \\
\hline $\begin{array}{l}\text { Lagu dengan } \\
\text { judul bahasa } \\
\text { Inggris }\end{array}$ & $\begin{array}{l}\text { "L.O.V.E", } \\
\text { "Secret Lover", } \\
\text { "Kiss Me", } \\
\text { "Song of Glory", } \\
\text { "Let's Go Party", } \\
\text { "Good Night } \\
\text { Sweetheart". }\end{array}$ & "KIS Lovers" & $\begin{array}{l}\text { "Beib"** } \\
\text { "Welcome", } \\
\text { "Aha... Aha... } \\
\text { Let's Do It" }\end{array}$ & $\begin{array}{l}\text { "Hangover", } \\
\text { "Full Moon", }\end{array}$ \\
\hline $\begin{array}{l}\text { Lagu dengan } \\
\text { judul bahasa } \\
\text { yang netral, } \\
\text { campuran, atau } \\
\text { samar-samar } \\
\text { ("tidak jelas") }\end{array}$ & "2501" & "B.D.K." & $\begin{array}{l}\text { "Na... Na... } \\
\text { Na...", "Rajib...", } \\
\text { "JPDA" } \\
\text { "UICG", } \\
\text { "(11.43)", } \\
\text { "Malami". }\end{array}$ & $\begin{array}{l}\text { "Sad but True } \\
\text { (Hati-hati)", } \\
\text { "Gue Sing } \\
\text { Takut", "Kota } \\
\text { Denpasar", } \\
\text { "Jogz" }\end{array}$ \\
\hline
\end{tabular}

Sumber : Diolah dari hasil observasi dan studi dokumen (2017).

Keterangan: * = Endrin di samping kata bahasa Bali juga Indonesi ** = Singkatan dari kata bahasa Inggris baby (sayang)

Dalam tabel tersebut, judul-judul lagu pada album pertama yang berbahasa Bali berjumlah 3, berbahasa Indonesia 2, berbahasa Inggris 6, dan berbahasa "tidak jelas" 1. Pada album kedua, judul-judul berbahasa Bali berjumlah 3, berbahasa Indonesia 8, berbahasa Inggris 1, dan berbahasa "tidak jelas" 1. Pada album ketiga, judul berbahasa Bali berjumlah 1 , berbahasa Indonesia 6 , berbahasa Inggris 3, dan berbahasa "tidak jelas" 7. Pada album terakhir, judul berbahasa Bali berjumlah 1, berbahasa Indonesia 5, berbahasa Inggris 2, dan berbahasa "tidak jelas" 4.

Campur-campur kebahasaan yang agak ekstrem terjadi dalam lagu yang maksud judulnya tidak begitu jelas, seperti B.D.K., pada album kedua. Dalam lagu ciptaan Krisna Purpa (Tu Krisna) tersebut, bahasa Bali-Indonesia-Inggris digunakan sedemikian rupa di bawah ini. Secara musikal, dan dilihat dari teori standar musik (yang mencakup nada, melodi, irama, dinamika), lagu ini sungguh bagus. Lebih dari itu, lagu ini bahkan tergolong mencekam perasaan atau setidaknya dalam bahasa anak muda sekarang disebut baper, atau membawa perasaan, sesuatu yang banyak terjadi dalam musik-musik Dani Ahmad, khususnya dalam album-album awal Dewa 19 ketika Ari Lasso masih menjadi vokalisnya.

\begin{tabular}{|c|c|}
\hline "B.D.K" & "B.D.K" \\
\hline Mesimpen di otak bli & $\begin{array}{l}\text { Tersimpan di otak } \\
\text { kakanda }\end{array}$ \\
\hline Menongos di hatin bli & Tinggal di hati kakanda \\
\hline $\begin{array}{l}\text { Sungguh sulit bli } \\
\text { mengerti }\end{array}$ & $\begin{array}{l}\text { Sungguh sulit kakanda } \\
\text { mengerti }\end{array}$ \\
\hline $\begin{array}{l}\text { Semua bisa saja } \\
\text { terjadi }\end{array}$ & Semua bisa saja terjadi \\
\hline Blingerti keneh adi & Bli mengerti hati adinda \\
\hline Keto masih keneh bli & $\begin{array}{l}\text { Demikian juga hati } \\
\text { kakanda }\end{array}$ \\
\hline $\begin{array}{l}\text { It was a sweet-sweet } \\
\text { memory }\end{array}$ & $\begin{array}{l}\text { Sebuah kenangan yang } \\
\text { sangat indah }\end{array}$ \\
\hline Keajaiban bagi bli & Keajaiban bagi kakanda \\
\hline Adi ngelut tekek bli & $\begin{array}{l}\text { Adinda memeluk erat } \\
\text { kakanda }\end{array}$ \\
\hline $\begin{array}{l}\text { Dingin di tongose } \\
\text { dini }\end{array}$ & Dingin di tempat ini \\
\hline Bli ngmales kiss adi & $\begin{array}{l}\text { Bli membalas ciuman } \\
\text { kakanda }\end{array}$ \\
\hline Dingin di beten & Dingin di bawah \\
\hline $\begin{array}{l}\text { Angine gelutin } \\
\text { sayong }\end{array}$ & Angin terpeluk kabut \\
\hline $\begin{array}{l}\text { Bulane engkebin } \\
\text { embun }\end{array}$ & $\begin{array}{l}\text { Bulan tersembunyi } \\
\text { embun }\end{array}$ \\
\hline $\begin{array}{l}\text { Nanging bintange } \\
\text { mesunar }\end{array}$ & Namun bintang bersinar \\
\hline $\begin{array}{l}\text { Otak bli terus } \\
\text { melayang }\end{array}$ & $\begin{array}{l}\text { Otak kakanda terus } \\
\text { melayang }\end{array}$ \\
\hline
\end{tabular}




\begin{tabular}{l|l} 
Bli ngerti keneh adi & $\begin{array}{l}\text { Kakanda mengerti hati } \\
\text { adinda } \\
\text { Demikian juga hati } \\
\text { keto masih keneh bli }\end{array}$ \\
It was a sweet, sweet & $\begin{array}{l}\text { Sebuah kenangan yang } \\
\text { sangat indah } \\
\text { memory }\end{array}$ \\
Keajaiban bagi bli & Keajaiban bagi kakanda
\end{tabular}

Ilustrasi 4.

Teks lagu "B.D.K" diambil dari album Jahat (2012).

Dalam kasus KIS Band dapat dinyatakan terdapat fenomena penyimpangan bahasa karena label/brand-nya adalah musik mebasa Bali tetapi kenyataannya syair/lirik lagunya ada yang berbahasa Indonesia dan bahkan Inggris. Dengan begitu, melihat bakat musiknya yang di atas rata-rata dalam peta musik pop Bali, pantas bagi KIS Band untuk melakukan apa yang dalam ilmu pemasaran disebut segmentasi pasar (market segmentation). Segmentasi pasar adalah tindakan melakukan pemilahan (membagi-bagi) pasar dengan mengembangkan musiknya dengan menambah produk-produk baru menjadi musik berbahasa Bali, musik berbahasa Indonesia, dan bila perlu musik berbahasa Inggris, sehingga ada tiga segmen (pangsa) pasar yang disasar, yaitu pasar musik pop Bali, pasar musik pop Indonesia, dan pasar musik pop Barat.

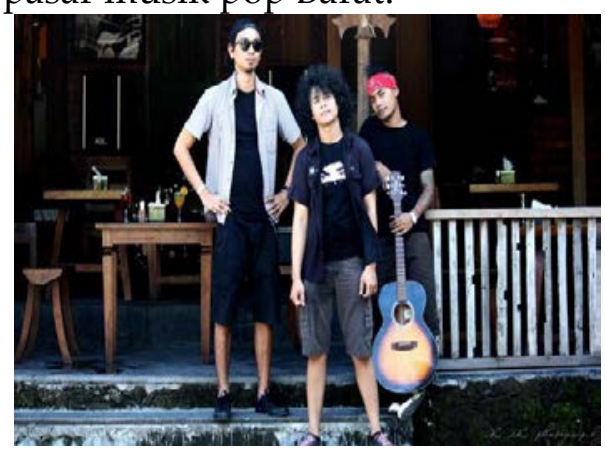

Ilustrasi 5.

KIS Band yang sangat sensasional dalam fenomena musik pop Bali di awal dasawarsa 2010-an (Foto: Repro/KIS Band, 2017).

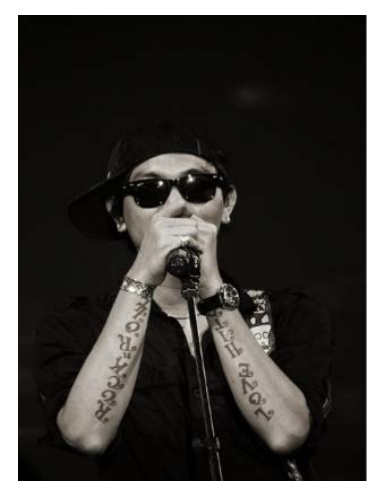

Ilustrasi 6 .

Krisna Purpa sebagai front man KIS Band (Foto: Repro/KIS Band, 2017)

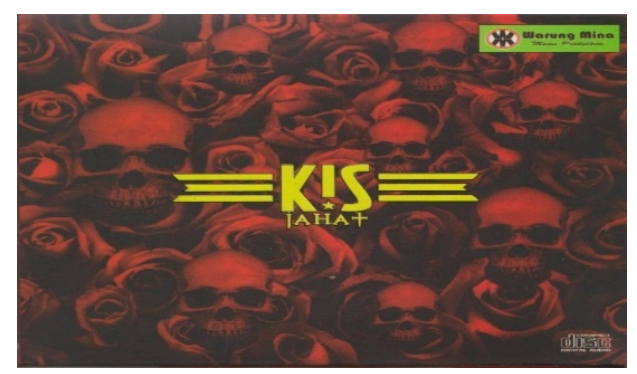

Ilustrasi 7.

Gambar cover depan (Foto: Repro/ KIS Band, 2017)

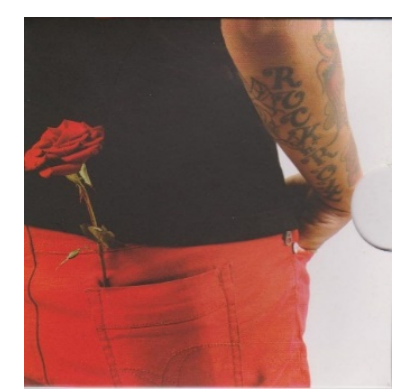

Ilustrasi 8.

Tampilan yang kurang menggambarkan kebalian (Foto: Repro/KIS Band, 2017)

Tentu saja sejumlah musisi pop Bali lainnya melakukan "kebocoran bahasa" atau dalam linguistik (ilmu bahasa) disebut campur/alih kode (code switching) meskipun tidak seintens KIS Band. Kebanyakan dari mereka seperti tidak secara sengaja melakukannya. Hal itu terjadi biasanya karena tidak ada padanan yang paling tepat untuk kata atau ekspresi tertentu dalam bahasa Bali, misalnya seperti kasus kata sayang yang sudah dijelaskan sebelumnya. Kalau demikian halnya, persoalannya bukan pada diri musisi 
tetapi bahasalah yang harus dikembangkan agar bisa merepresentasikan kehidupan masyarakat secara efektif. Prinsipnya, bahasa adalah produk kebudayaan karenanya ia harus dikembangkan secara terus-menerus sejalan perkembangan masyarakat pengguna bahasa tersebut. Di sinilah diperlukan tanggung jawab pemerintah dan ahli-ahli kebahasaan dalam memecahkan dan mengantisipasi persoalan sejenis.

Tentang persoalan bahasa Bali dan campur kode/bahasa dalam musik pop Bali, musisi (penyanyi, pencipta lagu, arranger) pop Bali yang juga penyiar RRI Denpasar Programa 4 Budaya I Putu Adi Sutirta dalam sebuah pernyataannya (Bali Post, Minggu, 27 Juli 2014) menyatakan,

"Apabila sor-singgih bahasa Bali yang digunakan dalam lirik lagu pop Bali bagus, pasti akan dicamkan oleh masyarakat yang mendengarkan dan masyarakat pun akan tahu bagaimana caranya berbahasa Bali yang baik. Namun, apabila sebaliknya, pasti akan menemukan masalah terkait bahasa karena banyak terdapat lagu yang menggunakan bahasa campuran, yaitu bahasa Bali dan Indonesia."

Dalam Teori Relasi Kekuasaan/ Pengetahuan Foucault, pandangan Sutirta tersebut adalah sebentuk diskursus atau tepatnya kontra-diskursus untuk melawan diskursus arus utama (mainstream). Sudah biasa terjadi bahwa bahasa musik pop adalah bahasa budaya populer dan bahasa budaya populer tidak sama dengan bahasa budaya tinggi yang dimaksudkan Sutirta. Sutirta tidak bisa disalahkan karena ada kecenderungan bahwa bahasa musik pop Bali akhirakhir ini terlalu bebas.

Di era globalisasi, dalam banyak musik pop daerah, campur kode (bahasa) terjadi secara tak terelakkan. Dalam musik pop Bali, harus diakui bahwa hal itu tampak begitu kentara. Kemampuan untuk tidak melakukan "campur-campur" seperti itu tentu tergantung dari daya kebertahanan bahasa Bali sendiri (maksudnya ketersediaan kosa/perbendaharaan kata yang cukup), kemampuan musisi bermain bahasa, dan masyarakat Bali sebagai pendengar musik pop Bali.

Kalau memang proses globalisasi terus berlangsung terhadap musik pop Bali, harus diyakini bahwa bahasa Bali adalah penjaga terakhir aspek-aspek kebalian musik pop Bali dalam industrialisasinya. Satu persoalan yang muncul dalam menghubungkan antara musik pop Bali dengan bahasa Bali adalah kecenderungan ketidakmampuan bahasa Bali dalam mengekspresikan perkembangan kehidupan masyarakat yang terus meningkat. Sebagai contoh adalah ketidakmampuan tidak saja bahasa daerah tetapi seluruh bahasa Indonesia misalnya dengan masuknya kehidupan global dan modern yang sebagian besarnya merupakan pengaruh Barat. Tidak banyak istilah bahasa Indonesia, apalagai bahasa daerah seperti bahasa Bali, yang mampu mewahanai istilahistilah Barat kecuali diciptakan kata-kata baru, yang bisa saja diterima tetapi lambat proses penerimaannya.

Bahasa Bali, khususnya dalam syairsyair musik (lagu) pop Bali, bahkan sejak lama tidak mampu mengekspresikan kata $a k u$ dan kamu secara proporsional sebagaimana yang hampir selalu muncul dalam syair-syair musik pop Indonesia sebagai padanan I dan you dalam syair-syair musik pop Barat (Inggris). Kata (ti)tiang dan jero atau ragane boleh saja digunakan tetapi sangat kaku dan kurang umum pada masa kini karena bahasa yang benar belum tentu bahasa yang baik. Terkait dengan aku dan kamu, kata beli untuk laki-laki dan adi untuk perempuan terlalu mengasumsikan bahwa pihak laki-laki lebih tua daripada perempuan padahal sekarang sering terjadi kasus di mana pihak laki-laki lebih muda daripada perempuan.

Dengan bertumpunya kepada bahasa Bali, sebagai konsekuensinya, musik pop Bali 
ke depan akan mengalami permasalahan tersendiri apabila bahasa Bali semakin lama semakin tidak mampu mengekspresikan perkembangan kehidupan manusia masa kini seperti yang terjadi saat ini. Perbandingannya adalah, kalau bahasa Bali perkembangannya seperti deret hitung, perkembangan kehidupan manusia berkembang dengan deret ukur. Keadaan ini tentu tidak ideal meskipun ini bukan fenomena khas bahasa Bali karena bahasa-bahasa kecil (daerah) lain juga mengalaminya. Dengan kata lain, kalau permasalahan tidak teratasi, akan semakin banyak dan sering terjadi penjajahan bahasa dalam industrialisasi musik pop Bali.

Kenyataan menunjukkan bahwa bahasa daerah Bali cenderung semakin ditinggalkan di Bali sendiri. Selain Bali semakin plural dengan semakin banyaknya etnis, agama, budaya, bahasa, dan cara hidup yang "bukan Bali", di kalangan masyarakat Bali sendiri, semakin banyak anak Bali yang tidak lagi menggunakan bahasa Bali sebagai bahasa sehari-hari, lebih-lebih di perkotaan. Anak-anak sekolah dan para mahasiswa lebih memilih bahasa Indonesia sebagai bahasa pergaulan di luar rumah dan di sekolah serta kampus. Orang tua pun secara sadar lebih memilih bahasa Indonesia dalam berkomunikasi dengan anak-anaknya untuk alasan keumuman (lebih umum), kemudahan (lebih mudah), kebermanfaatan lebih bermanfaat), bagi anak-anaknya. Dari sisi anak, bahasa Indonesia lebih memberikan nilai gengsi dibandingkan bahasa daerahnya.

Selama ini, tidak ada semacam upaya pengembangan bahasa Bali dari pihak-pihak berwenang, khususnya pemerintah. Dibandingkan perkembangan musik pop Bali, bahasa Bali mengalami involusi, sehingga tampak berjalan di tempat, kalau tidak mundur. Terkait dengan aspek produksi musik pop Bali, bahasa Bali tidak memiliki kosa kata (vocabulary words) yang melimpah untuk bisa dipilih dan digunakan dalam syair/lirik lagu. Akibatnya, banyak kata bahasa lain, terutama Indonesia, menggantikan bahasa Bali. Inilah yang disebut penjajahan bahasa dalam musik pop Bali. Dengan adanya involusi bahasa Bali, bahkan penurunan dalam aspek penggunaannya sehari-hari di masyarakat akibat kurangnya tanggung jawab moral untuk memertahankan bahasa Bali, wacana penghapusan bahasa Bali dalam kurikulum pendidikan, derasnya globalisasi yang menyebabkan keterpinggiran bahasa Bali, dan sebagainya, diperlukan semacam revolusi bahasa Bali dalam masyarakat Bali sendiri agar bahasa tersebut kembali mendapatkan perannya yang proporsional sebagai bahasa kehidupan sebagaimana yang terjadi pada era pertanian atau sebelum datangnya era pariwisata dan globalisasi seperti ini. Dengan itu, industrialisasi musik pop Bali akan semakin maju dengan semakin banyak dan berkualitasnya aspek-aspek produksi dan konsumsi yang mendukung.

Persoalan bahasa Bali ternyata bukan semata-mata persoalan internal produk-produk musik pop Bali itu sendiri. Menyadari bahwa musik (pop) Bali bermanfaat untuk melestarikan bahasa Bali, Ketua Pramusti Bali I Gusti Ngurah Murthana (Rah Man) menyatakan visi dan misi organisasinya memang melestarikan bahasa Bali melalui lagu (musik). Kepada penulis, Rah Man dalam sebuah acara musik di Kota Denpasar (tanggal 21 April 2013) menyatakan,

"Terus terang kami (Pramusti Bali) juga terketuk untuk ikut memperjuangkan bahasa Bali. Sejauh ini kan kami sudah berjuang dengan lagu Bali untuk melestarikan bahasa Bali tapi malah dihapus dari kurikulum. Ini (bahasa Bali) kan juga kearifan lokal yang mesti dipertahankan. Kami tetap mendukung menggunakan bahasa Bali dalam kurikulum pendidikan sebagai hak atas bahasa ibu." 
Melalui pernyataannya tersebut dan konfirmasinya melalui wawancara berikutnya tanggal 30 Maret 2015, Rah Man memiliki argumen yang logis, bahwa saat ini masyarakat Bali sudah biasa mendengar lagu-lagu mebasa Bali. Ketika mendengar lagu-lagu seperti itu, anak-anak (sebagai pengguna kurikulum pendidikan yang dikeluarkan pemerintah) bisa menyerap arti dari lirik-lirik lagu tersebut, sehingga, secara tidak langsung, mempelajari bahasa Bali. Pihaknya tetap mendukung bahasa Bali dalam kurikulum sebagai hak atas bahasa ibu (mother language).

Dalam kaitan Teori Relasi Kekuasaan/ Pengetahuan Foucault, Rah Man sedang mengemukakan pengetahuannya berupa diskursus pentingnya bahasa Bali dipertahankan dalam upaya ikut melestarikan musik pop Bali yang sudah jelas berbasis kebudayaan Bali, khususnya bahasa Bali. Setidaknya dalam konteks pengembangan musik pop Bali, diskursus pemberdayaan bahasa Bali tersebut seharusnya didukung oleh semua pihak terkait.

Tidak cukup dengan sejumlah elemen masyarakat Bali dan Pramusti Bali tetapi diperlukan upaya Pemerintah Provinsi (Pemprov) Bali untuk menyiasati keadaan tersebut agar bahasa Bali tetap bisa diajarkan di sekolah-sekolah dan perguruan-perguruan tinggi. Paling tidak, kinerja Pemprov Bali, termasuk Pemkab dan Pemkot di Bali, potensial menentukan keberadaan musik pop Bali dan industrialisasinya.

Musik pop Bali idealnya dapat dijadikan salah satu strategi untuk belajar bahasa Bali. Bertalian dengan persoalan tersebut, Sutirta berpendapat,

"Terkait bahasa Bali, lagu pop Bali bisa menjadi media komunikasi dan sarana pendidikan belajar bahasa Bali. Apalagi kalau lagu pop Bali sudah digemari, pasti akan sering didengarkan. Saking seringnya mendengarkan lagu tersebut, yang mendengarkan akan menghafal lagu yang bersangkutan.
Selain hafal, masyarakat yang mendengar juga akan meniru tatacara mengucapkan lirik-lirik lagu tersebut."

Sutirta menunjukkan keuntungan menyanyikan musik pop Bali. Maksudnya, dengan itu penikmat bisa belajar bahasa Bali sembari bisa menghibur diri dengan musik. Melihat kecenderungan semakin ditinggalkannya bahasa Bali bahkan oleh masyarakat Bali sendiri, cara belajar bahasa Bali seperti ini dapat dianggap bermanfaat. Dalam Teori Relasi Kekuasaan/Pengetahuan Foucault, pernyataan Sutirta tampak mendukung diskursus yang dikedepankan oleh Rah Man yang mendukung bahasa Bali tetap dipertahankan dalam kurikulum pendidikan. Jadi, diskursus Sutirta dan diskursus Rah Man ber-relasi sebagai sebentuk kekuasaan (meskipun kekuasaan tersebut tampak kecil dan tidak berdaya) dalam mencoba melawan, atau setidaknya mengkritisi, diskursus kekuasaan pemerintah yang meniadakan aspek-aspek kedaerahan (lokalisasi) yang sangat penting, yakni bahasa daerah.

\section{Penutup}

Musik pop Bali, melalui para musisinya, saat ini mengalami persoalan yang tidak ringan. Era global membuat produkproduknya semakin intens terkena modernisasi padahal ia harus mempertahankan konten lokalnya untuk menunjukkan bahwa musik yang diusung adalah musik pop Bali. Padahal, secara politik, musik pop Bali adalah penanda identitas kebalian yang membedakannya dengan masyarakat Jawa dengan musik pop Jawa dan masyarakat Batak dengan musik pop Bataknya.

Kecenderungan musik pop Bali dalam industrialisasnya pada saat ini justru semakin berkurangnya konten kebudayaan Bali di dalamnya. Musik pop Bali semakin tidak Bali karena aspek tangga nada tradisionalnya yang pentatonik (pelog dan/atau selendro) semakin digantikan gaya diatonik yang merupakan basik musik Barat (dan juga 
Indonesia). Pertahanan satu-satunya adalah bahasa, yakni bahasa Bali yang menjadi inti musik pop bali tetapi justru semakin lama semakin intens lirik/syair bahasa Balinya dicampur-campur bahasa asing, baik Indonesia maupun Inggris. Lagu-lagu yang muncul semakin tidak Bali, lebih-lebih yang dibawakan para musisi muda yang tampil sekadarnya di acara-acara televisi.

Terjadi pertarungan diskursus antara keinginan memertahankan bahasa Bali dan kekebasan berekspresi seniman musik pop Bali saat ini yang ingin tetap hidup dan eksis. Kebetulan saja ini merupakan era globalisasi di mana kekuasaan kapitalisne (para pemilik modal) bekerja sedemikian rupa sehingga pada dasarnya musik pop Bali dan terutama "bahasa Bali dalam musik pop Bali" sesungguhnya ada dalam posisi keterancaman. Karenanya dibutuhkan solusi dan komitmen dari berbagai pihak, yakni pemerintah, pemilik modal (musik), musisi, dan masyarakat untuk memperbaiki keadaan ini. Kalau tidak, musik pop Bali dalam pengertian yang sebenarnya bisa tinggal nama dalam beberapa masa ke depan.

\section{Daftar Referensi}

Althusser, Louis. 2008. Tentang Ideologi: Marxisme Strukturalis, Psikoanalisis, Cultural Studies (terjemahan Essays on Ideology). Yogyakarta: Jalasutra.

Bali Post. 2014. "Indik Basa Bali ring Lagu Pop Bali", Minggu, 27 Juli.

Barker, Chris. 2005. Cultural Studies: Teori dan Praktik (terjemahan Cultural Studies: Theory and Practice). Yogyakarta: Bentang.

Barker, Chris. 2014. Kamus Kajian Budaya (terjemahan The Sage Dictionary of Cultural Studies). Yogyakarta: PT Kanisius.
Fakih, Mansour. 1997. Analisis Gender dan Transformasi Sosial (Cetakan Kedua). Yogyakarta: Pustaka Pelajar.

Foucault, Michel. 2002. Pengetahuan dan Metode: Karya-karya Penting Foucault (suntingan, terjemahan Aesthetics, Method, and Epistemology, Essential Works of Foucault 1954-1984). Yogyakarta: Jalasutra.

Hardiman, F. Budi. 2009. Kritik Ideologi: Menyingkap Pertautan Pengetahuan dan Kepentingan bersama Jurgen Habermas. Yogyakarta: Penerbit Kanisius.

Martin, Gus (Ida Bagus Martinaya). 1999. "Musik Pop Bali itu, Keberagaman itu", makalah, Sarasehan Lagu Pop Bali, Yayasan Seni Denpasar dan Fakultas Sastra Universitas Udayana, Denpasar, 30 Juli.

Nordholt, Henk Schulte. 2007. Bali: An Open Fortress 1995-2005, Regional Autonomy, Electoral Democracy, and Entrenched Identities. Singapura: NUS Press.

Takwin, Bagus. 2003; 2009. Akar-akar Ideologi: Pengantar Kajian Konsep Ideologi dari Plato hingga Bourdieu. Yogyakarta: Jalasutra.

Takwin, Bagus. 2008. "Membaca Althusser dalam Beberapa Sisi: Sebuah Pengantar kepada Esai-esai Ideologi Althusser", Pengantar buku Tentang Ideologi: Marxisme Strukturalis, Psikoanalisis, Cultural Studies (terjemahan Essays on Ideology). Yogyakarta: Jalasutra, hal. xv-xxvi.

\section{Diskografi}

KIS Band. 2010. KIS\#1 (Number One) (album). KIS Band. 2012. Jahat (album). KIS Band. 2013. Sakit Jiwa (album). KIS Band. 2014. Story of Me (album) . [XXX]. 2011. Nak Bali (album). 